\title{
RURAL DEVELOPMENT PROGRAMME AS AN INSTRUMENT OF FINANCIAL SUPPORT FOR AGRICULTURAL PRODUCER GROUPS IN POLAND
}

\author{
Marzena Lemanowicz ${ }^{1}$ PhD \\ ${ }^{1}$ Warsaw University of Life Sciences
}

\begin{abstract}
In the article, principles of granting financial aid within the Rural Development Programme aimed at agricultural producer groups are discussed. Producer groups and organizations play an important role in Polish agriculture. Through group activity Polish farmers obtain numerous benefits, achievement of which would be impossible if they acted on their own. Since Poland joined the European Union, entities could receive financial aid within the Rural Development Programme. In the 2014-2020 programming period, conditions to receive financial aid have significantly changed in comparison to previous periods. Most of all, financial support was aimed only at new groups which were approved before 1 January 2014 at the latest. Moreover, groups gathering producers of poultry, poultry meat (fresh and chilled), and fruit and vegetables groups were excluded from receiving financial aid within RDP 2014-2020. By 30 September 2017, Agricultural producer groups were paid nearly 240 million EUR. Introducing new restrictive regulations concerning support for producer groups and organizations may contribute to a breakdown of the process of creating these entities. Data indicate that the number of agricultural producer groups decreased significantly in comparison to e.g. 2013 when new legal regulations had not been applied yet. The aim of the paper is to discuss the mechanism of providing financial aid to agricultural producer groups within the Rural Development Programme. Analyses have been performed for three programming periods: 2004-2006, 2007-2013 and 2014-2020 (as of 30.09.2017).
\end{abstract}

Key words: agricultural producer groups, producer organisations, Rural Development Programme, cooperation, integration.

JEL code: D23, Q13, Q14

\section{Introduction}

The integration of farmers has a very long tradition in Poland. In times of the centrally planned economy, agricultural cooperatives had a very strong position. The economic system at the time ensured cooperatives with sources and conditions to purchase goods, guaranteed cheap loans, set the costs of basic items and determined the level of sales prices and margin amounts. The scope of activities of agricultural cooperatives was very broad. However, the entities were not enterprises with an entrepreneurial spirit, with a skill to take risks or use marketing activities. Therefore, as a result of social and economic changes, a significant decrease in the scope of activities and the role of cooperatives in Polish agriculture was observed. The crisis in cooperatives caused that Polish agricultural producers - deprived of care from cooperatives - were not able to function on the market. Gradually, attempts to undertake common actions in the form of agricultural producer groups were made. Initially, the process was very slow, as after the collapse of cooperatives farmers lost trust in the common form of management. However, on the other hand the market required large batches of agricultural products which would be prepared for sale, sorted, properly marked etc. The requirements could not be met by individual farmers. Therefore, despite the collapse of agricultural cooperatives, farmers started to think about undertaking group actions. The legal act regulating establishment of agricultural producer groups was adopted in 2000; however joining the European Union increased the pace of farmers organizing themselves. An important element related to joining the EU, which undoubtedly contributed to the establishment of producer groups, was the creation of a mechanism to provide financial aid to such entities. Achieving other benefits would not be such a strong stimulus to intensify actions in this aspect. In terms of financial aid for agricultural producer groups, the main role in this aspect was played by the Rural Development Programme, within which since 2004 financial funds to support operations of such entities have been provided for. 
The objective of the article is to discuss the mechanism of providing financial aid to agricultural producer groups within the Rural Development Programme. Analyses have been performed for three programming periods: 2004-2006, 2007-2013 and 2014-2020 (as of 30.09.2017). One of the research tasks is to present the amount of financial aid granted due to the product category for which the group was created and as well as overview of the changes in the rules for granting financial aid to agricultural producer groups, according to the rules of the RPD 2014-2020. Secondary data obtained from the Agency for Restructuring and Modernization of Agriculture and the Ministry of Agriculture and Rural Development as well as literature on the subject was used in the analyses.

\section{Status of farmers being organized into agricultural producer groups}

Adoption of the act on agricultural producer groups of 15 September 2000 (Journal of Laws No. 88 , item 983 , as amended) constituted a chance to commence a systemic organization process for farmers. The act entering into force ensured groups being created use of national public aid measures. However, only Poland's entry into the European Union and providing support to the groups according to the Community principles definitely increased interest of producers in creating groups. Conditions of financial aid for agricultural producer groups being created significantly improved.

When it comes to the notion of an "agricultural producer group" it is worth mentioning that it does not mean any specific legal form. This term refers to an organization of the main goal, which is to launch products produced by farms of the members. Farmers can choose a legal form to be a cooperative, a limited liability company, an association or a society. As of 30 December 2017, in terms of selecting the legal form, limited liability companies and then cooperatives were the most popular.

Producer groups or organizations operate on the market among other economic entities. Therefore, they are subject to the same economic principles, competing for markets with national and foreign entities. Their operations are also justified in numerous economic theories, among others in neoclassical economics, new institutional economics or social economy. In neoclassical economics, a significant condition to undertake integration activities of agricultural producers is an imperfect market structure. It can be observed in the form of market asymmetry and large differences in the market strength of the participants in the food chain. In accordance with neoclassical economics, a method to reduce the lack of market balance between agricultural producers and other market participants is horizontal integration which involves common activities in the form of agricultural producer groups (Lemanowicz M., 2017). Establishing producer groups is also justified in new institutional economics, in particular in terms of transaction cost optimization. In the theory of transaction costs, the fundamental research unit is a contract, and contracts concluded by groups are always accompanied by various costs, which can be included among transaction costs (Coase R.H., 1993; Williamson O.E, 1998). They are costs incurred at the stage of seeking an opportunity to conclude a contract, seeking partners, entering into a contract, its execution and potential costs of problem solving after entering into a contract (Hardt L., 2009; Gorynia M., Mroczek K., 2013).

As mentioned before, despite the fact that the act on agricultural producer groups was adopted in 2000, a clear increase in the interest in creating agricultural producer groups could be observed from the moment Poland joined the European Union (2004), and even more so from the moment 
financial aid for such entities was commenced. In 2001, eight agricultural producer groups were registered in Poland; while in 2004, there were 94, and in January 2018 - 970 entities. Development of agricultural producer groups between 2001 and 2018 is presented in Figure 1.

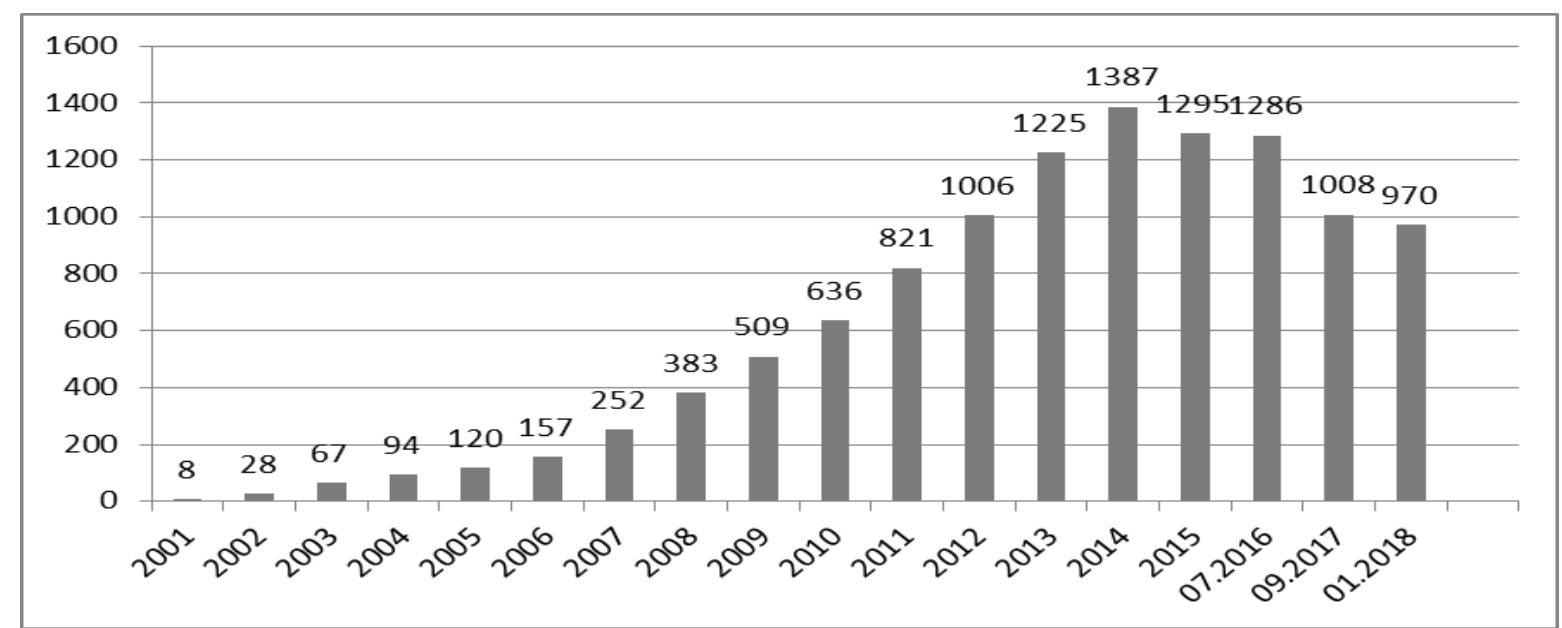

Source: the author's own study based on data from the Agency for Restructuring and Modernisation of Agriculture. Register of agricultural producer groups, www.arimr.gov.pl

Fig. 1. The number of agricultural producer groups in Poland in the years 2001-2018

Most agricultural producer groups function in product categories, such as: live pigs and pork, cereal grains and live poultry. The number of agricultural producer groups has been decreasing since 2015, which is caused by an amendment of the act on agricultural producer groups (...) of 11 September 2015 (Journal of Laws 2015, item 1888) entering into force. Not all groups functioning on the market filed applications for recognition and approval of a business plan within the required timeframe, and therefore were removed from the register of agricultural producer groups.

Thanks to acting as a group, farmers can win a lot of benefits, which would be either very difficult or even impossible in case of dispersed individual actions. Among basic benefits that farmers can obtain from horizontal integration, we can list a stronger competitive position of farmers in the market, improvement of economic efficiency of agri-production, better opportunities to create a base for storage, trade and processing, all due to joining capital, conclusion of favourable contracts and distribution of risk to all group members. It can also help to implement and develop marketing orientation of producers in the market (Adamowicz M., Lemanowicz M., 2004; Krzyzanowska K., 2016). Malchar-Michalska also underlines the significant role of producer groups in the vertical coordination of transactions in agriculture (Malchar-Michalska, 2018).

\section{Principles for granting financial aid to groups within the Rural Development Programme}

A significant factor for the development of group activity in Polish agriculture is financial support for such entities, which is granted within the Rural Development Programme. The Rural Development Programme is an instrument to execute the European Union policy in terms of development of rural areas in Poland. The document specifies objectives, priorities and principles concerning activities with an expected budget for their implementation. Based on this, specific activities related to social and economic development of rural areas are supported financially. Currently, Poland is within the 2014-2020 programming period, and before financial aid was granted - within the RDP 2004-2006 and RDP 2007-2013. While the principles to provide financial support to agricultural producer groups between 2006 and 2006 and between 2007 and 2013 were similar, then since 2014 significant changes were introduced in the conditions in providing financial 
aid. Between 2004 and 2006, 25.4 million EUR was provided for financial aid to agricultural producer groups; the budget for 2007-2013 was 554 million EUR (Krzyzanowska K., Trajer M., 2011). Within the RDP 2014-2020 financial plan, an amount of nearly 403 million EUR (including approx. 110 million EUR for commitments related to payments under measure 142 "Agricultural producer groups" RDP 2007-2013) was provided for support of agricultural producer groups (www.armir.gov.pl).

As mentioned before, principles to grant financial aid to groups within the Rural Development Programme in 2004-2006 and 2007-2013 were similar. Financial aid was granted as lump sum aid in the form of annual instalments over the first five years counted from the date of entering an agricultural producer group into the register. Financial aid was calculated based on the annual net value of income from the sale of products produced by farms being members of the group and it was in subsequent years respectively:

- $5 \%, 5 \%, 4 \%, 3 \%$ and $2 \%$ of the sold production value, if it did not exceed 1 million EUR, or

- $2.5 \%, 2.5 \%, 2 \%, 1.5 \%$ and $1.5 \%$ of the sold production value which exceeded 1 million EUR.

The amount of financial aid in a given year could not exceed: in the first and second year 100.000 EUR, in the third year - 80.000 EUR, in the fourth year - 60.000 EUR and in the fifth year - 50.000 EUR. When it comes to the principles to grant financial aid to agricultural producer groups within the RDP 2014-2020, it should be underlined that financial aid was aimed only at new agricultural producer groups, consisting of natural persons only, and which were approved not earlier than on 1 January 2014. Moreover, the following producer groups were excluded from receiving financial aid: live poultry, poultry meat (fresh and chilled) and fruits and vegetables.

Financial aid is executed in the form of annual payments in the 5 -year period and it is: in the first year - $10 \%$, in the second year - $8 \%$, in the third year $-6 \%$, in the fourth year $-5 \%$, in the fifth year $-4 \%$ of net income of the group from the sale of products produced by agricultural farms being its members. The aid limit is 100.000 EUR for each year of the 5-year support period. Table 1 presents the amount of financial aid paid to agricultural producer groups within the Rural Development Programme 2004-2006, 2007-2013, 2014-2020.

Financial aid paid to agricultural producer groups within RDP 2004-2006, RDP 2007-2013, RDP 2014-2010 (payments as of 30.09.2017)

\begin{tabular}{|l|c|c|c|}
\hline Specification & RDP 2004-2006 & RDP 2007-2013 & RDP 2014-2020 \\
\hline Amount of paid financial aid in PLN & 74.154 .436 .18 & 914.726 .584 .07 & 4.511 .960 .83 \\
\hline Amount of paid financial aid in EUR* & 17.868 .538 .83 & 220.416 .044 .30 & 1.087 .219 .47 \\
\hline
\end{tabular}
*according to approximate exchange rate 1 EUR=4.15 PLN
Source: data obtained from the Agency for Restructuring and Modernization of Agriculture on the basis of the
author's application

When it comes to financial aid granted to agricultural producer groups because of the product, for which they were established, the highest financial aid was received by groups created in the following categories: live poultry, meat or edible poultry offal - approx. 76.289.943 EUR; live pigs, piglets, weaners, pork - approx. 52.047.488 EUR; cereal grains and oilseeds - approx. 40.817.914 EUR. Table 2 presents the amount of financial aid paid to groups divided into product categories for which groups were created. The amounts provided concern support given within the RDP 2004-2006 and RDP 2007-2013. 
Financial aid paid to agricultural producer groups within RDP 2004-2006, RDP 2007-2013, divided into product categories (as of 30.09.2017)

\begin{tabular}{|l|r|r|r|r|}
\hline \multirow{2}{*}{\multicolumn{1}{|c|}{ Product category }} & \multicolumn{2}{c|}{$\begin{array}{c}\text { Financial aid amount } \\
\text { RDP 2007-2013 }\end{array}$} & \multicolumn{2}{c|}{$\begin{array}{c}\text { Financial aid amount } \\
\text { RDP 2004-2006 }\end{array}$} \\
\cline { 2 - 5 } & \multicolumn{1}{|c|}{ PLN } & \multicolumn{1}{c|}{ EUR* } & \multicolumn{1}{c|}{ PLN } & \multicolumn{1}{c|}{ EUR* } \\
\hline Live poultry, meat, poultry & 309.714 .114 .50 & 74.629 .907 .10 & 6.889 .148 .35 & 1.660 .035 .75 \\
\hline Pigs, piglets, pork & 194.795 .444 .18 & 46.938 .661 .22 & 23.512 .917 .28 & 5.665 .763 .20 \\
\hline Cereal grains and oilseeds & 155.905 .153 .12 & 37.567 .506 .77 & 13.489 .90 .43 & 3.250 .407 .33 \\
\hline Cow milk & 80.036 .366 .46 & 19.285 .871 .43 & 8.998 .663 .70 & 2.168 .352 .70 \\
\hline Cereal grains & $63.680 .047,47$ & 15.344 .589 .75 & 6.117 .950 .81 & 1.474 .205 .01 \\
\hline Oilseeds & 43.897 .817 .01 & 10.577 .787 .23 & 4.689 .211 .09 & 1.129 .930 .38 \\
\hline Birds' eggs & 17.270 .489 .88 & 4.161 .563 .83 & 3.218 .422 .12 & 775.523 .40 \\
\hline Potatoes & 13.108 .385 .69 & 3.158 .647 .15 & 1.472 .259 .21 & 354.761 .26 \\
\hline Sugar beets & 11.045 .974 .46 & 2.661 .680 .59 & 851.377 .80 & 205.151 .28 \\
\hline Cattle, beef & 10.659 .887 .10 & 2.568 .647 .49 & 663.478 .87 & 159.874 .43 \\
\hline Other & 14.612 .904 .17 & 3.521 .181 .73 & 4.251 .816 .52 & 1.024 .534 .10 \\
\hline Total & $\mathbf{9 1 4 . 7 2 6 . 5 8 4 . 0 7}$ & $\mathbf{2 2 0 . 4 1 6 . 0 4 4 . 3 0}$ & $\mathbf{7 4 . 1 5 4 . 4 3 6 . 1 8}$ & $\mathbf{1 7 . 8 6 8 . 5 3 8 . 8 3}$ \\
\hline
\end{tabular}

* according to approximate exchange rate 1 EUR $=4.15$ PLN

Source: data obtained from the Agency for Restructuring and Modernization of Agriculture on the basis of the author's application

Financial aid received by agricultural producer groups within the RDP 2014-2020 up until 30 September 2017 is not significant; however, it should be mentioned that in Q3 of 2017 only the second call for funding applications was made and the data presented in table 1 includes only the first tranche of payments. The sum of the points obtained for the group based on various criteria decides about the order of granting aid within action 9 "Creating producer groups and producer organizations" (RDP 2014-2020). It should be mentioned that the preferred legal form is a cooperative for which the largest number of points can be obtained as well as organizing a group in terms of selected products, such as e.g. organic farming products, live pigs, piglets, weaners, pork or live cattle, beef, sheep, live goats, slaughter animals or farmed animals, sheep wool, sheep or goat meat, sheep or goat skins, natural honey or other bee products, plants cultivated for energy purposes as well as hop cones. Furthermore, a factor affecting the ranking position is the number of group members. If a group consists of at least 10 members - a larger number of points is given, and for each subsequent group member - additional points are given. It is an important criterion which may encourage the creation of larger entities than the required minimum five members. The evaluation criteria also include investments planned by a given group in their business plan. If investments contributing to implementation of cross-cutting purposes of RDP 2014-2020, i.e. 1) increasing innovation - by introducing new production, process or technology rules, different from those currently in use and 2) counteracting climate change or environmental protection - by using machines, devices, equipment or technology, limiting adverse impact on the natural environment, or solutions limiting the use of resources, in particular water or energy, are planned, then such investments also receive a higher number of points. However, it should be remembered that financial aid within the RDP 2014-2020 is aimed only at new producer groups or organizations, i.e. groups or organizations which were approved not earlier than on 1 January 2014. Introduction of such a requirement significantly limited access to financial aid for groups which are already functioning on the market. To sum up, it should be underlined that having the status of an approved agricultural producer group and an approved business plan constitutes a necessary 
condition to be able to apply for financial aid within action 9 "Creating producer groups and producer organizations". Approval of an agricultural producer group and a business plan takes place by means of an administrative decision upon request of the concerned group.

Referring to the presented amounts of financial aid grated to agricultural producer groups, it should be clearly underlined that thanks to such aid agricultural producer groups received nearly 240 million EUR up until 30.09.2017 to support the process of their creation and development. It should be mentioned that execution of action 9 within RDP 2014-2020 is going to take several more years; therefore, the amount of financial aid granted to agricultural producer groups will be even higher.

\section{Conclusions}

1) Agricultural producer groups and producer organizations play a very important role in development of Polish agriculture.

2) Group activity in agriculture has a very long tradition, previously known as cooperatives. However, development of Polish cooperatives was hampered by political changes started in 1989.

3) Currently we can observe the rebirth of group farmers' activities according to new principles based on new legal acts. A significant element which accelerated the process of farmers organizing themselves into groups was financial support for agricultural producer groups.

4) The Rural Development Programme is an important financial instrument supporting the development of group activities in agriculture.

5) Thanks to the programme, agricultural producer groups received approx. 240 million EUR of financial support (payments up until 30.09.2017 were taken into account).

6) Principles to grant financial aid within the Rural Development Programme 2014-2020 have been changed significantly, limiting access to financial aid only to new groups (approved not earlier than 1 January 2014).

7) It was decided that the legal form which received the largest number of points when applying for financial aid is a cooperative. At the same time, it is underlined that larger entities, consisting of more than 10 members, should be established, which will ensure a higher ranking position.

8) Limiting access to funding and introduction of new legal regulations related to the approval of groups caused a decrease in the number of registered groups.

\section{Bibliography}

1. Act of 15 September 2000 on Agricultural Producer Groups and Their Associations, and Amendment of Other Acts (Journal of Laws No. 88, item 983, as amended)

2. Act of 11 September 2015 on Amending the act on Agricultural Producer Groups and Their Associations, and Amendment of Other Acts and the Act on Supporting Rural Development with the Participation of the European Agricultural Fund for Rural Development under the Rural Development Programme for 2014-2020 (Journal of Laws 2015, item 1888)

3. Adamowicz, M., Lemanowicz, M. (2004). Role of Horticultural Agri-producer Groups in Improving Competitiveness of Polish Agri-producers, Proceedings of the XVth International Symposium on Horticultural Economics and Management Book Series: Acta Horticulturae, Berlin, Issue: 655 pp. 403-412.

4. Coase, R. (1993). The Nature of the Firm: Influence, In: The nature of the firm. Origins, evolution, and development. Eds. Williamson, O.E., Winter S.G. Oxford University Press, New York, Oxford, pp. 61-74.

5. Data obtained from the Agency for Restructuring and Modernisation of Agriculture (November 2017).

6. Gorynia, M., Mroczek, K. (2013). Koszty transakcyjne jako determinanta formy zagranicznej ekspansji przedsiebiorstwa (Transaction Costs as Determinant of the Foreign Expansion of the Enterprise). Ekonomista, no 2, pp. 201-219. 
7. Hardt, L. (2009). Ekonomia kosztow transakcyjnych - geneza i kierunki rozwoju (Economics of Transaction Costs - Genesis and Directions of Development). Wydawnictwo Uniwersytetu Warszawskiego, Warsaw.

8. Malchar-Michalska, D. (2018). Pionowa koordynacja transakcji w rolnictwie (Vertical Coordination of Transactions in Agriculture). Wydawnictwo Dyfin, Warsaw.

9. Krzyzanowska, K. (2016), Ekonomiczno-spoleczne uwarunkowania innowacji w zespolowym dzialaniu w rolnictwie (Economic and Social Determinants of Innovation in Group Activity in Agriculture). Wydawnictwo SGGW, Warsaw.

10. Krzyzanowska, K., Trajer, M. (2011). Pomoc finasowa dla grup producentow rolnych w ramach dzialania 142 "Grupy producentow rolnych" PROW 2007-2013 (Financial Assistance for Agricultural Producer Groups in the Framework of the Measure 142 "Agricultural Producer Groups" PROW 2007-2013). Studies\&Proceedings of Polish Association for Knowledge Management, no 56, pp. 85-95.

11. Lemanowicz, M. (2017). Problematic Aspects of the Functioning of Agricultural Producer Groups and Organizations in the Light of Economic Theories. The Evolution of Group Activities in Polish Agriculture In: Agrarian \][ Perspectives XXVI: Competitiveness Of European Agriculture And Food Sectors, Eds. Tomsik, K. Book Series: Agrarian Perspectives Series, pp190-197.

12. Register of Agricultural Producer Groups, http://www.arimr.gov.pl/zadania-przekazywane-z-agencji-rynkurolnego/grupy-i-organizacje-producentow/rejestry-prowadzone-przez-arimr/rejestr-grup-producentowrolnych.html. Access: 20.01.2018.

13. Williamson, O.E. (1998). Ekonomiczne instytucje kapitalizmu. Firmy, rynki, relacje kontraktowe (The Economic Institutions of Capitalism. Firms. Markets. Relational Contracting). PWN, Warsaw. 